\title{
Rodzina w czasach wspótczesnego chaosu aksjonormatywnego
}

\section{Family in Time of Modern Axiological and} Normative Chaos

\begin{abstract}
ABSTRAKT
Przyczyna przemian dokonujących się we współczesnej rodzinie jest ogrom zmian w otaczajq̨cej nas rzeczywistości i będq̨cy ich konsekwencja współczesny chaos aksjonormatywny, który ogarnia niemal wszystkie przestrzenie życia człowieka. W poniższym tekście podięte zostanq rozważania odnośnie do tego, jak wpływa on na postrzeganie znaczenia więzi rodzinnych, a tym samym na relacje interpersonalne członków tradycyinej wspólnoty rodzinnej oraz takich typów rodzin, jak wspólnoty wielorodzinne czy rodziny alternatywne. Zostanie podięta również próba pokazania jak te przemiany powoduja zróżnicowanie w różnych zakresach świadomości wychowawczej rodziców i w kulturze pedagogicznej wielu środowisk. Bazując na literaturze przedmiotu, tekst ma na celu również zwrócenie uwagi, że przemiany te postrzegane sq zwłaszcza w pojmowaniu istoły małżeństwa i rodziny oraz w sposobach wypełniania przez nie zasadniczych funkcii, szczególnie funkcji pedagogicznych. Podejmując ten temat, należy się przyirzeć również źródłom zachodzqcych zmian i ich następstwom. Dynamiczne zmiany, jakie dokonuja się w życiu rodziny, wymagaja nie tylko dalszych jej badań, ale także nowych podejść metodologicznych i strategii poznawczych.
\end{abstract}

StOWA KLUCZOWE chaos aksjonormatywny, wspólnota rodzinna, więzi rodzinne, formy rodzinne, funkcje rodziny

\section{KEYWORDS}

axiological and normative chaos, family community, family ties, family forms, family functions

SPI Vol. 22, 2019/2

ISSN 2450-5358

e-ISSN 2450-5366

DOI: 10.12775/SPI.2019.2.002

Nadesłano: 28.03.2019

Zaakceptowano: 06.06.2019

Artykuły i rozprawy 
The reason for the changes taking place in the contemporary family and its new forms of life is the the wide scale of changes in the surrounding reality and the modern axiological and normative chaos that encompasses almost all spaces of human life. In the following text, consideration will be given to how this chaos affects the perception of the importance of family ties, and thus the interpersonal relationships of members of the traditional family community and of such types of families as multi-families or alternative families. An attempt will be made to show how these transformations result in diversity in the various ranges of parental awareness and the pedagogical culture of many environments. Based on the literature of the subject, the text also aims to draw attention to the fact that these changes are especially perceived in the understanding of the essence of marriage and family and the ways in which they fulfill essential functions, especially pedagogical functions. When addressing this topic, one should also look at the sources of changes and their consequences. Dynamic changes that are taking place in the families require not only further research, but also a new methodological approaches and cognitive strategies.

\section{Wprowadzenie}

Rodzina była i jest przedmiotem refleksji filozofii oraz badań licznych nauk humanistycznych (np. literatury, historii, filologii, etnografii), a także nauk społecznych (socjologii, psychologii, pedagogiki). Jest także obiektem zainteresowań teologii, medycyny, prawa, demografii, ekonomii i wielu innych. Dzięki swoim badaniom, tak teoretycznym, jak i empirycznym wypracowały one w różnych zakresach szczegółowych własne obszary dociekań nad rodziną, kreując tym samym w miarę autonomiczne subdyscypliny, którym w zależności od reprezentowanej dziedziny czy dyscypliny nadaje się odrębne nazwy (socjologia rodziny, psychologia rodziny, pedagogika rodziny, teologia małżeństwa i rodziny, medycyna rodziny, prawo rodzinne itp.). Ich dorobek ma $z$ reguły charakter multidyscyplinarny oraz interdyscyplinarny, bowiem wspólnym przedmiotem badań jest rodzina poznawana w typowym dla danej nauki aspekcie z uwzględnieniem ustaleń dokonanych przez pozostałe. Taki stan rzeczy pozwala niektórym 
uczonym postulować holistyczne podejście do wyników badań i objąć je nazwą familiologia, która scalałaby wiedzę o rodzinie mającą swoje źródło we wszystkich subdyscyplinach zajmujących się rodziną. Póki co, nie wiadomo, czy ten zamysł ma szansę urzeczywistnienia.

Pedagogika rodziny, pretendująca do jednej z subdyscyplin nauk pedagogicznych, charakteryzuje się tym, że koncentruje swoje zainteresowania badawcze na wychowawczych, socjalizacyjnych i edukacyjnych funkcjach rodziny. Nie znaczy to, że nie są one również postrzegane w pozostałych naukach o rodzinie. Każda z nich na swój sposób dookreśla termin rodzina, którą bada w kontekście stawianych przez nie pytań i problemów badawczych stosując własne, nierzadko specyficzne i zarazem odmienne metodologie.

\section{Współczesna rodzina - wspólnotą o jakościowo zmieniającej się więzi}

Rodzina jest terminem różnie określanym na gruncie poszczególnych nauk, w tym nauk pedagogicznych. Na użytek tego tekstu przyjmiemy założenie, że rodzina jest szczególnym i niepowtarzalnym bytem społecznym, którego właściwością jest wspólnotowy charakter życia określonego zbioru podmiotów zespolonych w różnym stopniu więzami biologicznymi, emocjonalnymi, kulturowymi i gospodarczymi. Podejście tradycyjne nakazuje traktować małżeństwo jako fundament rodziny'. Małżeństwo jako związek jednego mężczyzny z jedną kobietą jest wytworem prawodawstwa rzymskiego, zaś chrześcijaństwo połączyło skutki prawne zawarcia małżeństwa z ceremonią religijną i uznało je za sakrament, który obowiązuje do dzisiaj w Kościele rzymskokatolickim.

1 Małżeństwo jako związek jednego mężczyzny z jedną kobietą jest wytworem prawodawstwa rzymskiego. Chrześcijaństwo połączyło skutki prawne zawarcia małżeństwa $z$ ceremonią religijną i uznało je za sakrament, który obowiązuje do dzisiaj w Kościele rzymskokatolickim, ale niekoniecznie w pozostałych kościołach chrześcijańskich. Dopiero Napoleon Bonaparte w kodeksie cywilnym z 1804 roku nadaje małżeństwu świecki charakter, dopuszcza rozwody i poddaje sprawy małżeńskie sądownictwu powszechnemu. 
Aktualna i formalnie obowiązująca w świetle prawa definicja małżeństwa mówi o nim jako o dobrowolnym i równorzędnym związku kobiety i mężczyzny.

Konstytucja RP z 1997 roku traktuje małżeństwo jako „związek kobiety i mężczyzny” (art. 18), którzy są kreatorami wspólnoty, jaką jest rodzina. $Z$ kolei stanowisko Kościoła rzymskokatolickiego, odwołujące się do prawa kanonicznego jednoznacznie stwierdza, że rodzina jest oparta „na małżeństwie, gdzie wzajemny dar z samego siebie, mężczyzny i kobiety, stwarza takie środowisko życia, w którym dziecko może się urodzić i rozwijać swe możliwości, nabywać świadomość własnej godności i przygotować się do podjęcia swego jedynego i niepowtarzalnego przeznaczenia"2.

Tymczasem dostępne opinii publicznej wyniki badań, zwłaszcza nauk społecznych pokazują, że tradycyjny model małżeństwa i rodziny we współczesnym świecie jest już tylko jednym z możliwych, a w dodatku zmieniającym się dynamicznie. Przemiany cywilizacyjno-kulturowe ostatnich dziesięcioleci spowodowały, że pojawiły się nowe formy i sposoby funkcjonowania małżeństw oraz rodzin. Nie znaczy to, że nie zachowały one form wspólnotowych, których właściwością są szczególnie ważne więzy wpływające na relacje ich podmiotów, zdecydowanie różniące je od innych społecznych wspólnot. Dokonujące się przemiany powodują w coraz większym stopniu zmianę jakościową więzów małżeńsko-rodzinnych. Warto zatem zwrócić uwagę na najważniejsze $\mathrm{z}$ nich.

Doświadczenie i obserwacja życia społecznego, a także liczne badania dopowiadają, że wi ęz y bi ologi cz ne nie są obecnie warunkiem (conditio sine qua non) zaistnienia rodziny, chociaż powszechnie wiadomo, że do jednej z ważniejszych funkcji każdej rodziny należy prokreacja polegająca na powoływaniu do życia potomstwa oraz zaspokajaniu potrzeb rodzicielskich mężczyzny i kobiety, co jest podstawą nawiązywania autentycznych więzi interpersonalnych pomiędzy członkami wspólnoty rodzinnej. Tymczasem nietrudno dostrzec, że spada ogólna liczba zawieranych związków małżeńskich, a młodzi ludzie - zwłaszcza o wyższym poziomie wykształcenia i kwalifikacji zawodowych - opóźniają decyzję o zawarciu związku małżeńskiego

2 Jan Paweł II, Adhortacja apostolska Familiaris consortio, Rzym, 22 listopada 1981. 
i założeniu rodziny, upowszechniają się heteroseksualne związki kohabitacyjne, czyli świadomie rezygnujące $\mathrm{z}$ formalnego zawarcia cywilnego lub wyznaniowego związku małżeńskiego, oraz związki partnerskie wśród osób o homoseksualnej orientacji, domagające się prawa zawarcia związków na zasadach małżeńskich i adopcji dzieci. Ponadto na dużą skalę występuje zjawisko bezpłodności tak kobiet, jak i mężczyzn, powszechne staje się samotne rodzicielstwo, rodzi się coraz więcej nieślubnych dzieci, rośnie liczba adopcji dzieci przez osoby samotne, występuje zjawisko „zastępczych” czy „biologicznych” matek, tzw. surogatek, wzrasta liczba rozwodów, separacji oraz unieważnień sakramentu małżeństwa, upowszechnia się styl życia w „pojedynkę", czyli tzw. singli.

Słabnie siła więzi emocjonalnych w rodzinie. Przyczyną tego jest przekształcanie się tradycyjnych rodzin wielopokoleniowych w rodziny „nuklearne" z minimalną liczbą osób, coraz bardziej upowszechnia się przekonanie o tym, że rodzina przestała być wspólnotą nierozerwalną i dozgonną dla małżonków, opartą na miłości, zaufaniu i wierności; następuje rozluźnienie więzi uczuciowych pomiędzy członkami rodziny wyrażające się w braku dążeń identyfikacyjnych i ekspansywnych utrzymujących poczucie przynależności do tej samej wspólnoty. Współczesne małżeństwa i rodziny nie są wolne od nabywania lub porzucania poszczególnych osób, czyli dzieci, współmałżonków, także rodziców i dziadków należących bądź przypisanych do tej wspólnoty. Często nawet mało istotne niepowodzenia, zatargi, różnice zdań, porażki zawodowe, brak satysfakcji seksualnej, przewlekła choroba somatyczna któregoś z członków rodziny, czy nadwrażliwość psychiczna stają się potwierdzeniem dość powszechnych przekonań, że małżeństwo i rodzina nie muszą trwać wiecznie, dozgonnie, skoro nie gwarantują poczucia satysfakcji czy szczęścia. Współczesna rodzina coraz bardziej zatraca umiejętność głębokiego przeżywania wspólnoty, angażowania się oraz bycia dla siebie, ale i dla kogoś. Jej członkowie, zwłaszcza małżonkowie, coraz częściej czują się zwolnieni z „obowiązku” starania się, zabiegania, naprawiania czy dzielenia się swoimi osobistymi problemami, smutkami, porażkami bądź odnoszonymi sukcesami, zwłaszcza gdy nikt z rodziny nie przyczynił się bezpośrednio do ich osiągnięcia. Taki stan rzeczy wywołuje u poszczególnych osób wspólnoty rodzinnej poczucie złudnej autonomii i jest przyczyną wchodzenia w kolejne związki. 
Najpierw następuje rozpad więzi emocjonalnych, dochodzi do separacji, rozwodu i/lub unieważnienia związku małżeńskiego, a następnie do ponownego, a nawet wielokrotnego zawierania kolejnych związków małżeńskich lub wchodzenie w nowe związki partnerskie.

Przeobrażeniom podlegają małżeńskie i rodzinne więzy kultu rowe, u podstaw których leży wiele różnych czynników i wyznaczników. Chociaż pochodzenie społeczne/środowiskowe, wykształcenie i wiek małżonków nie odgrywają już takiej roli jak przed wieloma dziesięcioleciami, to jednak zdajemy sobie sprawę z tego, że normy zwyczajowe, obyczajowe, tradycja, sposoby interpersonalnego komunikowania się są czynnikami wzmacniającymi więzy kulturowe w rodzinie. Są one regulatorami codziennego jej funkcjonowania. Te wszystkie elementy, które wnosi się do współżycia małżeńsko-rodzinnego, są swoistym bagażem wyniesionym $\mathrm{z}$ rodzin pochodzenia. Bywają one nierzadko przedmiotem sporu i rzutują na klimat oraz atmosferę życia rodzinnego. Dotyczy to także, a może nawet przede wszystkim małżeństw „międzynarodowo mieszanych”, których liczba na skutek integracji państw europejskich oraz procesów globalizacyjnych zaczyna wzrastać. Różne style życia wyniesione przez małżonków/partnerów $z$ własnych rodzin pochodzenia, jeśli nie przekształcają się w przynajmniej akceptowany przez obie strony styl, z reguły prędzej czy później stają się problemem, niekiedy nawet nierozwiązywalnym. Wówczas zagraża im realne zerwanie więzi $\mathrm{z}$ poszczególnymi podmiotami $\mathrm{w}$ rodzinie.

Jednym $\mathrm{z}$ licznych wyznaczników więzi kulturowych w rodzinie jest stosunek tej wspólnoty do religii i praktyk z nią związanych. We współczesnym krajobrazie kultury europejskiej narasta oczekiwanie większej wolności i tolerancji religijnej, które uwyraźniają się w selektywnym doborze i przestrzeganiu nakazów i zakazów wyznaniowych. W znacznie mniejszym stopniu wspólnoty rodzinne uzasadniają wybór i kierowanie się wartościami chrześcijańskimi, po prostu traktują je jako wartości uniwersalne stanowiące źródło prawnych regulacji życia i współżycia obywatelskiego. Religijność jako element więzi kulturowych w rodzinie nie zawsze odgrywa rolę jednoczącą tę wspólnotę. Niewłaściwie rozumiana i manifestowana religijność doprowadza do ukrytej lub jawnej obojętności a nawet wrogości wobec samej wiary, a zwłaszcza jej form i sposobów wyznawania. Wszechobecne procesy laicyzacyjne powodują, że religia nie odgrywa dawnej 
roli w zakresie utrzymania i umacniania więzi w rodzinie. Sprawa wiary staje się coraz bardziej intymnym i osobistym wymiarem życia duchowego ${ }^{3}$ każdego człowieka, także każdego członka wspólnoty rodzinnej. Wspólnoty te ograniczają się do organizowania inicjacji religijnej poprzez chrzest czy komunię św. małoletnich dzieci. Dorastająca młodzież nierzadko sakrament bierzmowania traktuje jako swoisty symbol rozstania ze wspólnotą wyznaniową.

Zagrożeniem dla więzi rodzinnych jest nieumiejętność wypełniania przestrzeni osobowej uznawanymi wspólnie w rodzinie tych samych wartości. Coraz bardziej każde kolejne pokolenie kieruje się zróżnicowaną hierarchią wartości, tworzy własne jej systemy, nadaje im nowe znaczenia Więzy kulturowe, które niegdyś silnie łączyły rodzinę, zdają się być coraz bardziej pozorne, gdyż cechuje je daleko idąca powierzchowność.

Współczesne rodziny doświadczają zmian w zakresie łączących je więzów gospodarczych, czy wręcz ekonomicznych. Zwiększa się wzajemna niezależność materialna małżonków, gdy oboje mają swoje własne źródła zarobkowania. Natomiast zmniejsza się ona, gdy nie znajduje stałej pracy jedno lub oboje rodziców. Wówczas egzystencja jednego z nich zależy od drugiego współmałżonka. Jakość więzów ekonomicznych podlega zmianom, gdy nie respektuje się obowiązku alimentacyjnego przez jednego z rodziców lub konieczność finansowania dorosłych, ale niesamodzielnych gospodarczo niekiedy dorosłych dzieci. Jest również tak, że dorosłe i usamodzielnione materialnie potomstwo z różnych powodów i przyczyn nie wspiera finansowo rodziców, chociaż ciąży na nich taki obowiązek zarówno moralny, jak i prawny, zwłaszcza wówczas, kiedy zachodzi taka konieczność.

Różne, zwłaszcza podstawowe więzi rodzinne należy postrzegać jako czynniki warunkujące stabilność i trwałość wspólnoty osób tworzących rodzinę. Wymienione więzi rodzinne wzajemnie się przenikają, dopełniają, ale także częściowo lub całkowicie wykluczają wpływając na jej kondycję.

3 Przez życie duchowe, czyli duchowość człowieka rozumiem określony styl jego relacji z Bogiem i środowiskiem, wyróżniający się swoistymi cechami oraz formami działalności. 
Reasumując należy stwierdzić, że rodzinę łączą liczne więzi, ale ich siła i znaczenie staje się coraz bardziej problematyczne. I nie ma tu znaczenia, czy małżonkowie/rodzice zawarli związek cywilny, czy sakramentalny, czy tworzą wspólnotę bez formalnego związku. Przemiany cywilizacyjno-kulturowe, którym towarzyszy narastający chaos aksjonormatywny ${ }^{4}$, a więzi rodzinne zmieniają się jakościowo, właściwościami tej wspólnoty pozostają niezmiennie: autentyczne poczucie współprzynależności do konkretnej rodziny, aktywne współuczestnictwo w codziennym życiu rodziny oraz pełna świadomość współodpowiedzialności za tworzoną przez siebie wspólnotę.

Autentyczna wspólnota rodzinna nie jest jednostką organizacyjną powołaną do realizacji wyznaczonych jej zadań. Nie ma ona charakteru usługowego, ani konsumenckiego. Jest podmiotem ze wszech miar twórczym, zdolnym do wzajemnego i bezinteresownego poświęcania się w imię wspólnie osiąganego dobra, które determinują właściwie pojmowane i urzeczywistniane więzi. Zmieniająca się jakość więzi rodzinnych rzutuje na jakość jej codziennego życia, wypełniania obowiązków i powinności przypisanych rolom pełnionym przez jej członków. Ograniczony lub częściowy, bądź całkowity brak więzi stanowi zasadniczą przeszkodę w budowaniu wspólnoty. Przy niskim poziomie samoświadomości ról poszczególnych członków tej wspólnoty, rodzinie zagraża dysfunkcjonalność - jeśli nie całkowita, to przynajmniej częściowa, chociaż bywa niekiedy, że tylko okresowa. Aby przeciwdziałać takiemu procesowi relacje osobowe w rodzinie winny opierać się na wzajemnej miłości, zaufaniu, uczciwości, szacunku i wyrozumiałości dla słabszych stron jej wszystkich podmiotów.

\section{Źródła przemian zachodzqcych w tradycyjnej rodzinie i ich następstwa}

Wielopostaciowe procesy globalizacyjne, ruchliwość przestrzenna i społeczna współczesnych ludzi, wszechobecna wielokulturowość, a także procesy laicyzacyjne i sekularyzacyjne powodują ustawiczne i systematyczne przemiany, jakie dokonują się w tradycyjnej rodzinie, tak w wymiarze świadomościowym, obyczajowym,

4 Przez termin chaos aksjonormatywny rozumiem zamęt, nieład, nieprzestrzeganie norm, których źródłem jest świat uznawanych powszechnie wartości. 
moralno-etycznym, jak i prawnym oraz ekonomicznym. To za ich sprawą w coraz większym stopniu zanika także tradycyjny podział na role męskie i kobiece, które decydowały o formach życia rodzinnego, niezmienności porządków w strukturze i hierarchii wartości oraz obowiązków i powinności przypisanych członkom rodziny.

Współczesna rodzina żyje w czasach wielkiego zamieszania i zagubienia w całym otaczającym ją świecie. Żyje ona w świecie wielorakich, nowych, niekiedy do końca nie zdefiniowanych potrzeb. $\mathrm{Na}$ plan pierwszy wysuwają się coraz bardziej potrzeby indywidualne poszczególnych osób w rodzinie. Pierwszoplanowe oczekiwania współczesnych kobiet i mężczyzn to: zdobycie optymalnego wykształcenia, satysfakcjonująca praca, w której można potwierdzić swoje kwalifikacje i kompetencje profesjonalne, awans zawodowy jako osobisty sukces, niezależność materialna, realizacja własnych pasji i zainteresowań, troska o urodę, dbałość o zdrowie, sprawność i kondycję fizyczną itp. Do nich można też zaliczyć - niestety coraz częściej jako drugorzędne - macierzyństwo, założenie rodziny poprzez związek małżeński lub partnerski. Oznacza to, że młodzi ludzie zawierają coraz rzadziej małżeństwa, zaś małżeństwa z kilkuletnim stażem coraz częściej się rozwodzą. W Polsce rozpada się już prawie co trzecie małżeństwo. Programy socjalno-pomocowe dla rodzin nie przynoszą efektów demograficznych, a jedynie wpływają na poprawę bytową rodzin wielodzietnych. Statystyki GUS informują, że rodzi się coraz mniej dzieci. Współczynnik dzietności, czyli liczba dzieci przypadających na jedną kobietę $\mathrm{w}$ wieku rozrodczym, sukcesywnie $\operatorname{spada}^{5}$. Tradycyjnie pojmowana funkcja prokreacyjna rodziny zostaje wypierana przez traktowanie życia seksualnego jedynie jako zasadniczej potrzeby popędowo-biologicznej będącej rzekomo najważniejszym czynnikiem rozwoju i życiu każdego człowieka. Potrzeba ta determinuje trendy kulturowe i zmiany mentalnościowe nadające życiu seksualnemu zdecydowane priorytety. Do nich należy zaliczyć: narzucanie erotycznej uczuciowości bez granic, kruchość i skłonności narcystyczne, wzmożoną pornografię i komercjalizację ludzkiego ciała. Ogromny wpływ na przeobrażania się współczesnych rodzin mają również ustalenia nauki, zwłaszcza seksuologii, która dokonuje

5 Na podstawie danych GUS z roku 2017. 
podziału na możliwe pięć orientacji seksualnych: heteroseksualizm, homoseksualizm, biseksualizm, autoerotyzm, aseksualizm ${ }^{6}$.

We współczesnych rodzinach często zamiast dzieci rodzą się dylematy dotyczące takich kwestii, jak przykładowo wymienione pytania: co łączy współmałżonków i rodziców z dziećmi, a co ich dzieli, różni? Jak okazywać sobie pozytywne uczucia, a jak walczyć z ich odwrotnością, zaprzeczeniem? Jakie stawiać sobie i innym członkom rodziny wymagania? Czy trwać w subiektywnie ocenianej negatywnie wspólnocie rodzinnej, czy ją opuścić, czyli zażądać rozwodu, separacji lub oddalić się na tyle, aby nie ograniczała osobistej wolności, która znosi odpowiedzialność za rodzinę, za rodziców, za rodzeństwo? Czy lepiej żyć samotnie, czy stadnie?

Współczesne rodziny coraz częściej stają się wspólnotami dysfunkcjonalnymi z powodu niedochowanie wierności małżeńskiej; alkoholizmu i narkomanii jednego lub obojga rodziców, ale także ich potomstwa; psychicznej nadwrażliwości lub jej braku; przepracowania rodziców na skutek nadmiernej eksploatacji ich potencjału oraz wadliwej organizacji pracy zarobkowej lub jej braku, co powoduje utratę środków materialnych, a dorosłemu potomstwu udaremnia lub w dużym stopniu ogranicza naturalne usamodzielnienie się; narasta zjawisko niewydolności wychowawczej rodziców.

Przyczyną a zarazem skutkiem dysfunkcjonalności współczesnej rodziny tradycyjnej jest narastający w globalnym świecie chaos aksjonormatywny, który prowadzi do nieznanych dotąd w takiej skali przemian w zakresie jej bytowego funkcjonowania. Dysfunkcjonalność obejmuje swym zakresem wszystkie obszary więzów rodzinnych: biologiczne, emocjonalne, kulturowe oraz ekonomiczne. I chociaż poddajemy je oddzielnemu opisowi i analizie, to w codzienności życia rodzinnego wchodzą one we wzajemne relacje, czyli przenikają się. Innymi słowy można powiedzieć, że albo całkowicie, albo tylko częściowo nakładają się one na siebie. Niektóre z nich mogą być przyczyną wywołującą skutek u innych i odwrotnie. Nie da się stworzyć holistycznego i jedynego modelu tych relacji, gdyż każda rodzina w sposób dla siebie jedyny i niepowtarzalny uwyraźnia istnienie bądź brak więzi, które ją łączą.

6 Pedofilia nie jest traktowana jako orientacja seksualna lecz jako choroba, podobnie jak zoofilia, gerontofilia, nekrofilia. 
Nie potrafimy zdefiniować w sposób jednoznaczny terminu rodzina dysfunkcjonalna, aby stał się on pojęciem uznanym przez ogół badaczy. Dla potrzeb dalszych rozważań przyjmiemy założenie, że rodzina dysfunkcjonalna to wspólnota, którą cechuje zaburzona komunikacja interpersonalna; która jest nastawiona na utrzymanie wewnętrznego systemu relacji, zamiast na rozwój członków rodziny; która nadużywa przemocy fizycznej i psychicznej; nadmiernie kontroluje lub w ogóle nie kontroluje zgodności zachowań swoich członków z obowiązującymi zasadami i normami życia społecznego, a wypracowuje jedynie dla własnych potrzeb nawyki służące jej nieprawidłowemu funkcjonowaniu. Taki stan rzeczy jest skutkiem, a zarazem następstwem takich zjawisk i procesów, jak:

- demoralizacja, która uwyraźnia się w upadku moralności, rozwiązłości obyczajów, braku karności i dyscypliny we wspólnocie rodzinnej;

- relatywizm moralny, który oznacza, że wartości etyczne (dobro i zło) oraz związane z nimi normy i oceny mają dla wspólnoty rodzinnej jedynie charakter względny i subiektywny;

- nihilizm etyczny, który jest wyrazem odrzucenia przez wspólnotę rodzinną uznawanych powszechnie norm, zasad, wartości natury społecznej, religijnej, estetycznej, etycznej, czy narodowej;

- deprawacja, przez którą należy rozumieć trwałe schodzenie lub całkowite zejście przez wspólnotę rodzinną na drogę niemoralną i aspołeczną, co czyni ją rodziną patologiczną.

Powyższe zjawiska i procesy skłaniają ku refleksji, u podstaw której leżą cztery zasadnicze kręgi pytań o charakterze aksjologicznym, psychologicznym, ekonomicznym i kulturowym. Oto ich przykłady, które z pewnością nie wyczerpują wszystkich szczegółowych zagadnień:

\section{Krąg aksjologiczny:}

1. Jakie miejsce zajmuje rodzina w osobistej, indywidualnej hierarchii wartości przez osoby, które tworzą tą wspólnotę?

2. Czy w świadomości członków wspólnoty rodzinnej jest ona jedyną powszechnie akceptowaną i dobrze postrzeganą w społeczeństwie formą życia człowieka? 
3. Jaki jest stosunek członków tradycyjnej wspólnoty rodzinnej do innych, odmiennych od niej form życia wspólnotowego ludzi?

\section{Krąg psychologiczny:}

1. Dlaczego warunkiem prawidłowego funkcjonowania rodziny są pozytywne stany emocjonalne, które łączą poszczególne podmioty tej wspólnoty?

2. W czym przejawia się miłość, wierność i uczciwość w relacjach pomiędzy członkami wspólnoty rodzinnej i do czego można je sprowadzić?

3. Jakie inne czynniki - poza wymienionymi wcześniej - w przestrzeni międzypodmiotowej rodziny mogą wpływać/wpływają na stany emocjonalne, motywy postępowania i zachowania poszczególnych jej członków?

\section{Krąg ekonomiczny:}

1. W jakim stopniu coraz bardziej zróżnicowane warunki bytowe poszczególnych rodzin przesądzają o jakości ich życia?

2. Jaką rolę odgrywa zasada „mieć lub być” w codziennym życiu wspólnoty rodzinnej?

3. Jakie skutki dla zachowania więzi członków wspólnoty rodzinnej niesie jej status materialno-ekonomiczny i społeczny?

\section{Krąg kulturowy:}

1. Czy pielęgnowanie tradycyjnych wzorów życia rodzinnego jest wystarczającym zabezpieczeniem przed zagrożeniami chaosu aksjonormatywnego, jaki zawładnął światem?

2. W jakiej mierze poziom świadomości wychowawczej i kultury pedagogicznej rodziców reprezentowany przez konkretne wspólnoty rodzinne wpływają na ich przeobrażenia, które mogą, ale nie muszą powodować utraty dotychczasowego znaczenia odgrywającego ważną rolę w życiu każdego człowieka?

3. Czy rodzina przestaje być „gniazdem cnót”, w które winna wyposażyć swoje potomstwo?

Poszukiwanie odpowiedzi na powyższe i im podobne pytania znajduje swoje uzasadnienie w założeniu mówiącym, że tradycyjny, 
wielowiekowy model rodziny nie jest już stabilny i nienaruszalny. Pod wpływem wielorakich zmian cywilizacyjno-kulturowych, jakim objęta jest współczesna Europa, a także globalny świat, które są następstwem różnych czynników zarówno natury subiektywnej, jak i obiektywnej, rodzina przestała być monolitem. Do ważniejszych w tym względzie czynników należy zaliczyć eksplozję demokracji, zwłaszcza liberalnej, która przyczynia się także do zmiany stosunku państwa do małżeństwa i rodziny. Wolność obywatelską rozszerzono na sprawy i różne podejścia do życia małżeńskiego i rodzinnego. Umacnia się przekonanie, że nie można naruszać ludzkiej autonomii, że każdy człowiek ma prawo do niczym nieskrępowanego życia intymnego, osobistego i prywatnego, które cechuje małżeństwo i rodzinę. Idea demokracji i wolności nie zawsze jest właściwie odczytana i rozumiana, zwłaszcza w odniesieniu do tradycyjnej wspólnoty rodzinnej, która zawsze była uznawana za najważniejsze naturalne środowisko człowieka. Efektem tych dążeń są pojawiające się nowe, a zarazem odmienne formy życia rodzinnego, których beneficjentami są nie tylko małżonkowie, ale także ich dzieci.

\section{Zmienność form życia małżeńskiego i wspólnot rodzinnych}

Współczesny chaos aksjonormatywny, który wpływa na życie całych zbiorowości ludzkich, takich jak naród, państwo, środowiska lokalne itp. dotyka także poszczególne osoby i małe wspólnoty, jak np. rodzina, których są członkami. Jest on czynnikiem nie tylko osłabiającym, czy rozluźniającym więzi międzyludzkie, lecz nierzadko niweczy je. Więzi te w dzisiejszych czasach przestały być uznawane jako wartości, które należy pielęgnować i traktować jako coś, co wymaga trudu, wysiłku, czy wręcz osobistego zaangażowania w ich ochronę. We współczesnej rodzinie stają się one bardziej towarem konsumpcyjnym, który podlega indywidualnej ocenie, aniżeli czymś ważnym, czy wręcz najważniejszym. Można zatem wchodzić w dowolne jakościowo relacje, zawierać związki małżeńskie lub partnerskie bez jakichkolwiek zobowiązań względem drugiej osoby. Można czuć się zwolnionym w tych związkach z obowiązku bycia ze sobą na dobre i na złe, w bogactwie i ubóstwie, w zdrowiu i chorobie. Wchodząc w związki małżeńskie lub w nieformalne związki partnerskie nie musi się rezygnować z osobistych korzyści, poszukiwać 
kompromisów i poświęcać dla konkretnego związku, który przestaje spełniać oczekiwania. Taka sytuacja daje człowiekowi poczucie wolności osobistej, indywidualnej, niczym nieskrępowanej, ale równocześnie niesie ze sobą określone niebezpieczeństwa ${ }^{7}$. Fascynacja i uleganie trendom ciągłego nabywania i wymieniania nie tylko dóbr materialnych, ale także przyswajania nowych bądź odrzucania uznawanych wartości, przekonań, stylów życia pozwala coraz częściej upatrywać w nich siły kreowania nowych warunków bycia. Toteż współczesna rodzina - jak nigdy dotąd - nie jest wolna od nabywania i porzucania poszczególnych osób, czyli małżonków, dzieci, a także rodziców, a nawet dziadków należących bądź przypisanych do tej wspólnoty. Mało istotne niepowodzenia, zatargi, różnice zdań, porażki zawodowe, brak satysfakcji seksualnej, trudna sytuacja materialna lub odniesienie spektakularnego sukcesu indywidualnego, przewlekła choroba somatyczna czy psychiczna, niesprawność wrodzona bądź nabyta potomstwa, nadwrażliwość psychiczna stają się potwierdzeniem poglądów głoszących, że małżeństwo i rodzina nie muszą trwać dozgonnie, zwłaszcza że nie gwarantują poczucia szczęścia osobistego. Można wręcz stwierdzić, że współczesna rodzina coraz częściej i z coraz większą determinacją zatraca umiejętność głębokiego przeżywania, angażowania się oraz bycia niejako dla siebie, ale przede wszystkim dla członków wspólnoty rodzinnej. Jej członkowie, zwłaszcza małżonkowie, coraz łatwiej czują się zwolnieni z "obowiązku” starania się, zabiegania, naprawiania czy dzielenia się problemami, smutkami, porażkami bądź odnoszonymi sukcesami, zwłaszcza gdy mają poczucie, że nikt z rodziny nie przyczynił się bezpośrednio do ich osiągnięcia. Daje to poczucie złudnej autonomii, która pozwala wchodzić w kolejne związki małżeńskie lub partnerskie. Ten stan rzeczy poprzedza rozpad więzi emocjonalnych, separacja, rozwód i/lub unieważnienie sakramentalnego związku małżeńskiego, a następnie ponowne, a nawet wielokrotne wchodzenie w nowe związki. Relacje międzyosobowe ulegają znacznym przemianom i są poddane różnym zagrożeniom. Powiększa się liczba rodzin rozbitych, niepełnych, związków nieformalnych, a w sferze intymnej następuje niemalże wyodrębnienie się życia

7 Por. Z. Bauman, Ptynna nowoczesnośc, Kraków 2006, s. 253. 
seksualnego ze sfery życia emocjonalnego ${ }^{8}$. Są to przejawy nierespektowania dotychczas obowiązujących norm i zasad zwyczajowych, obyczajowych, etycznych oraz religijnych sprzyjających załamywaniu się życia w tradycyjnej wspólnocie rodzinnej. Sytuacje takie są przejawem zataczającego coraz większe kręgi chaosu aksjonormatywnego, a także jego wzmożeniami. Trend ten próbuje się regulować za pomocą tworzenia nowych norm prawnych, mających na celu ich legalizację.

Takie podejście sprzyja dążeniom do usankcjonowania nowych form życia wspólnotowego, które w sposób istotny różnią się od modelu rodziny tradycyjnej. Przyjmują one $\mathrm{z}$ reguły dwie możliwe opcje, które określa się terminami wspólnota wielorodzinna oraz rodzina alternatywna.

Wspólnota wielorodzinna bywa nazywana też „rodziną akordeonową" (patchworkową) ze względu na jej swoistą rozciągliwość personalną oraz szczególną budowę opierającą się na różnych połączeniach i relacjach osób wchodzących w jej skład. Innymi słowy można powiedzieć, że jest to rodzina rozszerzona o nowe osoby. Są nimi osoby zajmujące miejsce męża lub żony, ojca lub matki w dotychczasowym związku, ich potomstwo z poprzednich związków, przyrodnie rodzeństwo, którego biologiczną matką lub ojcem są osoby wchodzące w nowy układ rodzinny oraz różni „dodatkowi” krewni i powinowaci, którzy w konsekwencji zmian dokonujących się w danej rodzinie pojawiają się w kolejnej wspólnocie.

Wspólnoty wielorodzinne nierzadko napotykają na bardziej uwyraźniające się w życiu codziennym problemy pedagogiczne $\mathrm{w}$ porównaniu $\mathrm{z}$ tradycyjnymi wspólnotami rodzinnymi. Ich źródłem są niejasno formułowane cele i dążenia wychowawcze przez „zrekonstruowane” małżeństwa, unikanie odpowiedzialności za przysposobione potomstwo, brak wzajemnego zaufania w zakresie stosowanych metod oddziaływań wychowawczych przez "nowych” i „dodatkowych” członków wspólnoty, nadopiekuńczość wobec biologicznego potomstwa, rutynowe czynności wychowawcze pozbawione empatii w odniesieniu do potomstwa przysposobionego, poczucie obcości w rodzinie zrekonstruowanej i wiele innych.

8 Por. P. Sztompka, Świat potrzebuje wizji, „Alma Mater. Miesięcznik UJ” 2002, nr 44. 
Schemat l. Relacje osobowe w nietradycyjnej wspólnocie wielorodzinnej

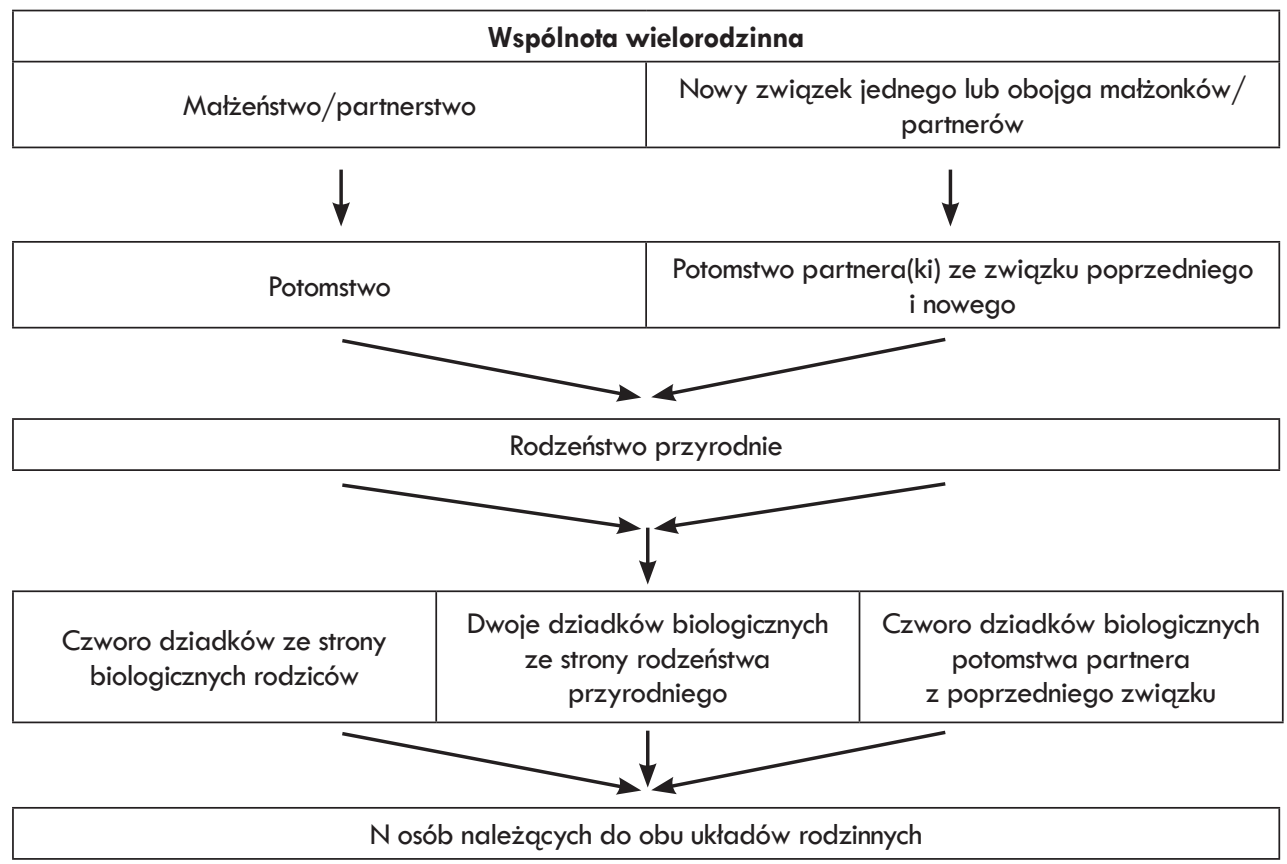

Źródło: Opracowanie własne.

Schemat 1 ukazuje wielorakie powiązania personalne, jakie zachodzą we wspólnocie wielorodzinnej. Rodzina ta staje się grupą, która przyjmuje postać pewnego układu społecznego składającego się z większej liczby osób pozostających w określonych relacjach względem siebie, wyrażających się pełnieniem ról w stosunku do siebie, nie zawsze wyraźnie określonych. Wspólnota wielorodzinna podejmuje próbę konstruowania nierzadko własnego systemu wartości oraz ustala normy regulujące zachowania jednostek w sprawach ważnych i drugorzędnych dla swojej wspólnoty, w której rodzice i dzieci, krewni i powinowaci występują z reguły w podwójnych rolach i zajmują określone pozycie w jej strukturze wewnętrznej.

Wspólnota wielorodzinna siłą rzeczy rozszerza się o nowe osoby: o potomstwo zrodzone $\mathrm{z}$ nowego związku, o potomstwo i jego biologiczną matkę lub ojca nowej partnerki lub partnera, także ich rodziców i rodzeństwo, czyli włączani są do niej „dodatkowi” dziadkowie i babcie, wujkowie i ciotki, stryjowie i stryjenki wraz z ich potomstwem. We wspólnocie wielorodzinnej, rozszerzonej o kolejne 
osoby problemem staje się zjawisko aleksytymii, czyli niezdolności do rozpoznawania i nazywania własnych emocji oraz komunikowania się z nowymi członkami wchodzącymi w zmieniony układ interpersonalny. Wchodzenie bądź niewchodzenie $\mathrm{w}$ relacje $\mathrm{z}$ poszczególnymi członkami rozszerzonej wspólnoty rodzinnej powoduje, że wiele osób przypisanych do niej nie potrafi uświadomić sobie i zrozumieć przyczyn swoich stanów emocjonalnych wywoływanych przez znalezienie się w nowej sytuacji. Dotyczyć to może nie tylko osób dorosłych, ale przede wszystkim dzieci i młodzieży należących do wielorodzinnej wspólnoty. I chociaż aleksytymią mogą być dotknięci także dorastający w rodzinach tradycyjnych, zwłaszcza w rodzinach dysfunkcjonalnych i patologicznych, to należy zakładać, że we wspólnotach wielorodzinnych może mieć ona znacznie szerszy zasięg. Członkowie wielorodzinnej wspólnoty dublują swoje role względem poszczególnych jej podmiotów. Na przykład: dziecko/potomstwo wielorodzinnej wspólnoty ma $z$ jednej strony swoją biologiczną matkę, ale aktualna żona/partnerka jego biologicznego ojca często stara się wejść w rolę quasi-matki. Podobnie jest w przypadku ojców, dziadków i innych członków takiej wspólnoty. W tej skomplikowanej sytuacji dziecko/potomstwo nie zawsze jest gotowe nawiązać autentyczne więzi międzyludzkie $z$ tymi osobami i ich quasi-rolami rodzinnymi. Jest też tak, że na przykład żona biologicznego ojca lub mąż biologicznej matki dziecka, albo inni członkowie wspólnoty wielorodzinnej, nie muszą lub nie chcą, albo też nie potrafią wejść w nową, niedookreśloną do końca rolę względem dziecka. Sytuacje takie mogą wywoływać w dziecku różne nieuświadomione doznania emocjonalne, których źródeł nie potrafi ono określić. Ich wyrazem jest lęk, płacz, kołatanie serca, zdenerwowanie, niczym nieuzasadniona pobudliwość i tym podobne reakcje. Świadczą one o tym, że dziecko nie jest zdolne do rozpoznawania własnych emocji, nie potrafi je kontrolować, nie wyzwala w sobie umiejętności empatycznych, czyli nie dostrzega doznań i uczuć osób z kręgu wspólnoty wielorodzinnej. Funkcjonowanie dzieci z syndromem aleksytymii jest często dość mocno zaburzone, chociaż niekiedy potrafią je doskonale maskować. Na ogół czują się one same ze sobą źle i wówczas zdarza się, że uciekają w świat odrealniony, czemu sprzyjać i służyć moga różnorodne używki, popadanie w nałogi, prowadzące do zespołu zachowań patologicznych. 
Wspólnoty wielorodzinne cechuje pewna różnorodność, która uwyraźnia się w postaci różnych form uzyskujących coraz większą akceptację społeczną, prawną a nawet kanoniczną. Przykładem jednej z nich są tzw. komuny rodzinne, które powstały na podstawie przyjętej przez parlament Danii ustawy o zalegalizowaniu małżeństw grupowych. Inną jest założona przez Instytut Ekumeniczny w USA grupa składająca się z 250 dorosłych oraz dzieci żyjących i mieszkających we wspólnocie, która prowadzi jedno ogólne gospodarstwo domowe, oddaje się wspólnym praktykom religijnym i wychowaniu dzieci. Jeszcze innym przykładem wspólnoty wielorodzinnej jest tzw. Fraternia Życia, która ma charakter ekumeniczny. Funkcjonują one za zgodą miejscowego biskupa na terenie wskazanej przez niego parafii Kościoła rzymskokatolickiego9. Wszystkie Fraternie Życia są zrzeszone w ogólnoświatowej wspólnocie Chemin Neuf od początków lat 70. XX wieku. Wspólnoty te w liczbie kilkuset działają na terenie 50. krajów i zrzeszają około 2000 dorosłych członków, nie licząc ich potomstwa.

Narastające tendencje w zakresie pojawiania się różnych form życia wspólnot wielorodzinnych są pewnym sygnałem świadczącym o dokonujących się zmianach w formach współczesnego życia rodzinnego. Zmiany w zakresie współczesnych form życia małżeńskiego i rodzinnego dostrzegł Alvin Toffler, który w odróżnieniu od tradycyjnych wspólnot rodzinnych nazwał je Rodzinami Alternatyw$n y m i^{10}$. Jego podział rodzin alternatywnych uwzględnia także wielorodzinne wspólnoty, o których była wcześniej mowa.

9 Pierwsza Fraternia Życia utworzona została w Lyonie (1971) przez kard. Alberta Decourtaya, który zatwierdził ją jako tzw. publiczne stowarzyszenie wiernych.

10 Por. A. Toffler, Szok przysztości, przeł. W. Osiatyński, Poznań 1998. 
Schemat 2. Typy rodzin alternatywnych

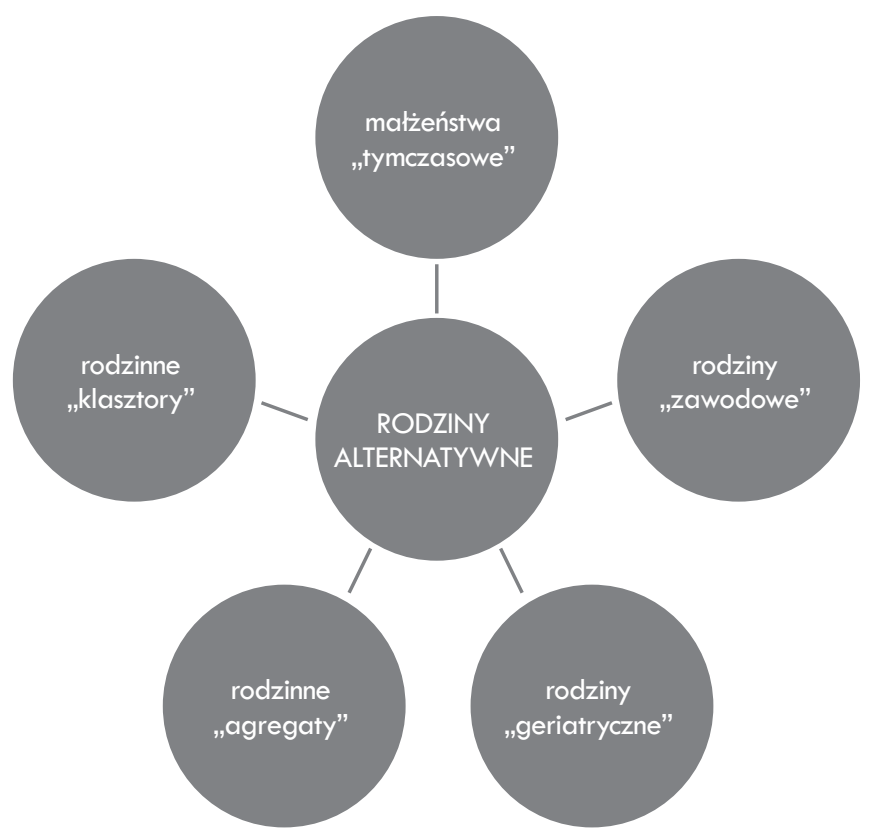

Źródło: Opracowanie własne.

Do rodzin alternatywnych Toffler zalicza tzw. małżeństwa "tymczasowe”. Użycie słowa „tymczasowe” świadczy o ich nietrwałości, gdy tymczasem warunkiem zaistnienia tradycyjnej rodziny jest ma1żeństwo zawarte przez mężczyznę i kobietę wzajemnie zobowiązujących się pod przysięgą/przyrzeczeniem do dozgonnego trwania we wspólnym związku. Małżeństwo „tymczasowe” bywa także określane jako małżeństwo „na próbę”. Związek taki z reguły spełnia wszystkie bądź większość funkcji małżeńskich, a wśród nich rozrodczą. Bywa tak, że to potomstwo takiego związku zachęca swoich rodziców do zawarcia związku małżeńskiego. Przyczyn niezawierania małżeństwa we współczesnym świecie przenikniętym chaosem aksjonormatywnym jest wiele. Jan Paweł II w adhortacji Familiaris consortio wymienia i uzasadnia je następująco:

Niektóre osoby czują się niemal przymuszone do tego rodzaju życia przez trudne sytuacje ekonomiczne, kulturowe i religijne, gdyż zawarcie prawidłowego małżeństwa naraziłoby je na szkody, na utratę korzyści ekonomicznych, na dyskryminację itd. (...) Natomiast u innych 
stwierdza się postawę pogardy, kontestacji i odrzucenia społeczeństwa, instytucji rodziny, porządku społeczno-politycznego albo też wyłączne poszukiwanie przyjemności. (...) Innych wreszcie popycha do tego zupełna nieświadomość i krańcowe ubóstwo, nieraz zaś uwarunkowania wynikające $z$ sytuacji rzeczywistej niesprawiedliwości, lub pewna niedojrzałość psychiczna, która sprawia, że są zbyt niepewni i bojaźliwi, by zawrzeć trwały i nierozerwalny związek. (...) W niektórych krajach tradycyjne zwyczaje przewidują zawarcie właściwego i prawdziwego małżeństwa jedynie po pewnym okresie wspólnego mieszkania i po urodzeniu się pierwszego dziecka ${ }^{11}$.

Z kolei „rodziny zawodowe” to wspólnoty, które za zgodą sądów rodzinnych podejmują się pełnić pieczę nad opuszczonymi, osieroconymi, bądź pozbawionych praw rodzicielskich dziećmi aż do osiągnięcia przez nie pełnoletniości, dojrzałości psychicznej oraz społecznej i samodzielności materialnej. W Polsce nazywa się takie rodziny „zastępczymi”. Niekiedy rolę opiekunów powierza się najbliższym krewnym dziecka (dziadkom, wujostwu, czasami starszemu rodzeństwu itp.), ale także bezdzietnym małżeństwom lub małżeństwom posiadającym własne potomstwo. Nadzór nad takimi rodzinami sprawuje państwo, samorządy lub inne instytucje i organizacje pożytku publicznego. Do ich zadań należy wsparcie finansowe a także pedagogiczne. Sytuacja dzieci wychowujących się w tego typu rodzinach bywa zróżnicowana, bowiem nie zawsze wstępne rozeznanie możliwości wypełniania przez nie funkcji opiekuńczych jest właściwe, obiektywne i optymalne. Dysfunkcje takich rodzin powoduja pozbawienie ich możliwości kontynuowania pieczy nad dziećmi im powierzonymi. Los dzieci w rodzinach zastępczych bywa nierzadko trudny i niekiedy nie przyczynia się do ich właściwego rozwoju osobowościowego. Świadomość dziecka bycia pozbawionym własnych rodziców, całkowitego lub częściowego z nimi kontaktu prowadzi u niego do utraty poczucia własnej tożsamości, co odbija się na jego życiu psychicznym i społecznym także po osiągnięciu samodzielności. Rodziny zastępcze bywają często krytykowane za niewydolność wychowawczą, niekiedy za popełnianie wykroczeń, a nawet przestępstw wobec powierzonych im dzieci. W takich sytuacjach szybka reakcja powołanych do nadzoru rodzin zastępczych instytucji musi być natychmiastowa i skuteczna. Rodzina zastępcza mimo swojej

11 Jan Paweł II, Adhortacja apostolska Familiaris consortio, dz. cyt., nr 81. 
niedoskonałości jest wspólnotą mającą na celu ochronę dzieci przed częściową lub całkowitą bezdomnością. Troska o dziecko zawsze wymaga jego całkowitego zabezpieczenia oraz rozwiązania problemów egzystencjalnych, emocjonalnych i społecznych.

Rodzina „zawodowa/zastępcza” to wspólnota, która wymaga od współczesnego społeczeństwa szczególnej uwagi, życzliwości i wyrozumiałości. Społeczeństwo zaś musi dołożyć wszelkich starań, aby spełniała ona swoje zadania mające na celu łagodzenie, a nawet naprawę następstw, jakie niesie ze sobą doświadczany przez wszystkich chaos aksjonormatywny.

Toffler w swojej typologizacji rodzin alternatywnych wymienia „rodziny geriatryczne”. Takimi rodzinami nazywa te, które tworzą wspólnotę składającą się z rodziców w wieku senioralnym wraz z samotnym dorosłym potomstwem. Liczba takich rodzin ustawicznie przyrasta. $Z$ jednej strony przyczyn takiego stanu rzeczy należy upatrywać w tym, że wydłuża się średnia wieku życia seniorów na skutek postępu medycyny,jej dynamicznie rozwijającej się technologii i nauk farmaceutycznych oraz ustawowego obniżania wieku emerytalnego. $\mathrm{Z}$ drugiej strony wchodzące $\mathrm{w}$ dorosłe życie pokolenie wydłuża czas zdobywania wykształcenia poprzez podejmowanie nauki równolegle na więcej niż jednym kierunku studiów, dochodzenia i nabywania umiejętności profesjonalnych, poszukiwaniu intratnej pracy wymagającej w coraz większym stopniu zaangażowania się w nią. Niesamodzielność ekonomiczna nie pozwala młodym ludziom na życie na własny rachunek, myślą oni o gromadzeniu takiej ilości środków materialnych, które w ich przekonaniu mogą stanowić punkt wyjścia do założenia własnej rodziny.

To oczywiście tylko niektóre przyczyny funkcjonowania tego typu rodzin. Wśród innych można także dostrzec m.in. chęć wygodnego życia młodych u boku rodziców, a tym samym na ich koszt. Taki stan rzeczy czyni młodych dorosłych osobami nieodpowiedzialnymi za siebie, ale również za starzejących się rodziców. W „rodzinach geriatrycznych" mimo ich wspólnotowego charakteru narasta zjawisko osamotnienia wśród jej członków. Sprzyja mu poczucie braku autentycznej więzi pomiędzy rodzicami a młodymi dorosłymi. Więź ta ma słabsze podłoże psychiczne, bowiem kształtuje ją podejście merkantylne, czyli nastawienie na pewne korzyści, które mogą być obustronnie nadużywane. Stany osamotnienia (także samotności) nie są obce 
także członkom rodzin tradycyjnych, jak i wspólnotom wielorodzinnym, a także rodzinom żyjącym we wszystkich alternatywnych związkach. Osamotnienie jest kategorią, za pomocą której można opisać psychiczną kondycję zarówno współczesnych dzieci, młodzieży, dorosłych, jak i seniorów. Osamotnienie rodzi się w nich wówczas, gdy naturalna więź z innymi członkami wspólnoty rodzinnej zostaje wewnętrznie wypierana przez brak intymnego kontaktu z najbliższymi. Osoba osamotniona, mimo że żyje we wspólnocie, nie odczuwa psychicznej satysfakcji z tego faktu, gdyż nie może liczyć na zaspokojenie potrzeby osobistego bezpieczeństwa czy uznania. Dotyczy to zarówno dorosłych dzieci jak i ich rodziców, z którymi pozostają we wspólnocie rodzinnej. Relacje pomiędzy nimi z reguły stają się jakościowo i ilościowo bardziej sformalizowane, aniżeli pozytywnie emocjonalne. Rodzicom w wieku senioralnym towarzyszy poczucie odpowiedzialnego wspierania dorosłych dzieci, które stają się coraz bardziej bezradne wobec otaczającej ich rzeczywistości, a tym samym zatracają zdolność do rozumienia sensu własnego życia. Stan osamotnienia nie jest wybierany przez członków tej wspólnoty w sposób świadomy i celowy, lecz staje się ich udziałem $w$ relacjach $\mathrm{z}$ najbliższymi i bywa głęboko uwewnętrzniany. $Z$ reguły dorosłe dzieci w „rodzinach geriatrycznych” wybierają w bliższej lub dalszej perspektywie życie samotne i przyczyniają się do wzrostu liczby tzw. singli w społeczeństwie.

„Rodzinne agregaty” to wspólnoty, które tworzą rozwiedzeni rodzice z nowymi partnerami i ich wspólne dzieci oraz potomstwo pochodzące z wcześniejszych związków małżeńskich/partnerskich. Nazwa tego typu rodzin jest niemalże zbieżna z nazwą „wielorodzinnej wspólnoty rodzinnej”. Natomiast „rodzinną komunę” tworzą wspólnoty składające się z większej liczby rodzin żyjących we własnych związkach małżeńskich, które kierują się podobnym stosunkiem do otaczającej je rzeczywistości, wspólnym stylem życia, dążeniami do realizacji wspólnych celów. „Rodzinnymi klasztorami”Toffler nazywa większe grupy wspólnotowe, które niekoniecznie mają, chociaż mogą mieć charakter wyznaniowy. Są nimi zatem także te, które określa się mianem „rodzinnymi komunami”. Można zatem uznać obie nazwy za bliskoznaczne, ale nie synonimiczne. Wielorodzinne wspólnoty, jak np. Fraternie Życia należą także do nich, lecz te - na co wskazano wcześniej - mają zdecydowanie charakter wyznaniowo-religijny. W tych wspólnotach chodzi o pogłębienie wiary i jej codzienne 
przeżywanie. To wraz z nimi mieszka kapłan, który troszczy się o zaspokojenie ich potrzeb religijnych i posługuje im duchowo.

Reasumując można powiedzieć, że poza modelem tradycyjnej rodziny, który nadal jest modelem wiodącym i powszechnym, pojawiają się coraz częściej w przestrzeni społecznej również nowe modele rodzin. Niektóre $z$ nich starają się zachować najważniejsze elementy życia rodziny tradycyjnej, ale ujawniają się one w innych, odmiennych wymiarach, a nawet postaciach. Pojawiają się one jako następstwo zmian cywilizacyjno-kulturowych, które wpływają na zmiany mentalności człowieka, jego wizji współczesnego świata, własnego miejsca oraz roli, jaką może on odegrać także w nieprzewidywalnej rzeczywistości. Sprawcą zmian polegających na odchodzeniu od modelu tradycyjnej rodziny i sprzyjaniu pojawiania się ich nowych modeli - jak już wcześniej powiedziano - jest współczesny chaos aksjonormatywny. Spowodowany jest on różnorodnymi kryzysami, jakie dotykają świat i ludzi, wielokierunkowymi procesami transformacyjnymi, społecznymi procesami integracyjnymi, ale także dezintegracyjnymi oraz procesami globalizacyjnymi. Wszystkie one swoim zasięgiem rzutują na wizje małżeństwa i formy życia rodzinnego. Dlatego coraz donioślej stawia się pytanie o przyszłość rodziny. Ferdynand Lundberg uważa, że współczesna rodzina jest „na wymarciu”. William Wolf twierdzi, że wkrótce jedyną funkcją rodziny będzie wychowanie dziecka w czasie ograniczonym do niezbędnego minimum. Z kolei Irvin Grynberg uważa, że ludzie przytłoczeni zmianami i wstrząsami, jakie nieuchronnie niosą nowe czasy, będą szukać w rodzinie stałości i pewności, będą zawierać małżeństwa, by zyskać stabilnośćc ${ }^{12}$.

Bez wyjątku każdy z ukazanych powyżej typów współczesnych rodzin $z$ istoty swej natury jest odpowiedzialny za kreowanie procesu wychowania, którego nadrzędnym celem jest formacja młodego pokolenia. Jego jakość i skuteczność zależy od przeświadczenia podmiotów wychowujących o konieczności odwoływania się do uznanych społecznie norm, wzorców i reguł postępowania służących optymalizacji działań wychowawczych. Tymczasem we współczesnych

12 Por. A.M. de Tchorzewski, Rodzina w kontekście wspótczesnych problemów egzystencjalnych i pedagogicznych, w: Z dziejów polskiej kultury i oświaty od średniowiecza do poczatków XX wieku, red. K. Jakubiak, T. Maliszewski, Kraków 2010, s. 431-442. 
rodzinach, które dotknięte są skutkami chaosu aksjonormatywnego wiele $\mathrm{z}$ nich nie funkcjonuje $\mathrm{w}$ świadomości osób odpowiedzialnych za wychowanie. Janusz Mastalski wyodrębnił aż dziewięć grup zaniedbanych paradygmatów formacyjnych młodego pokolenia, które stanowią ważną z punktu widzenia nauk pedagogicznych podstawę realnego procesu wychowania ${ }^{13}$.

Tabelal. Zaniedbane paradygmaty formacyine młodego pokolenia

\begin{tabular}{|c|c|}
\hline \multicolumn{2}{|r|}{ Paradygmaty } \\
\hline Teleologiczny & $\begin{array}{l}\text { Podstawq wychowania we wspólnocie rodzinnei jest świadomość celów, } \\
\text { ku którym zmierzajq wszystkie jej podmioty. }\end{array}$ \\
\hline Ograniczonego zaufania & $\begin{array}{l}\text { Skuteczność wychowania we wspólnocie rodzinnej zależy od stopnia } \\
\text { wzajemnego zaufania, którego nie może zabraknqć ani być w nad- } \\
\text { miarze. }\end{array}$ \\
\hline Kontrolowanej samodzielności & $\begin{array}{l}\text { Wspólnota rodzinna dla dobra właściwego rozwoju potomstwa re- } \\
\text { zygnuje z nadopiekuńczości, na rzecz dyskretnego wdrażania procesu } \\
\text { samowychowawczego. }\end{array}$ \\
\hline Indywidualnego podejścia & $\begin{array}{l}\text { Wspólnota rodzinna uwzględnia potencjalne możliwości każdego } \\
\text { potomka i dostosowuje zarówno cele i metody wychowania do jego } \\
\text { osobistych dyspozycji. }\end{array}$ \\
\hline Detoksykacyiny & $\begin{array}{l}\text { Wspólnota rodzinna ma za zadanie optymalizować warunki służqqce } \\
\text { i gwarantujqqce integralny rozwój potomstwa. }\end{array}$ \\
\hline Wychowanie przez obecność & $\begin{array}{l}\text { Wspólnota rodzinna jest zobligowana do ksztaltowania relacji interper- } \\
\text { sonalnych na jej wzajemnej obecności fizycznej i duchowym byciu.. }\end{array}$ \\
\hline Destereotypizacyjny & $\begin{array}{l}\text { Wspólnota rodzinna przeciwstawia się wszechobecnym stereotypom } \\
\text { postrzegania człowieka i otaczajq̨cej go rzeczywistości doceniajq̨c to } \\
\text { wszystko co stanowi niekwestionowane wartości. }\end{array}$ \\
\hline Ekologiczny & $\begin{array}{l}\text { Wspólnota rodzinna stanowić winna środowisko syntoniczne, czyli takie, } \\
\text { w którym rozumie się uczucia, pragnienia i reakcje wszystkich jej pod- } \\
\text { miotów, dzięki czemu łatwiej one nawiqzuja kontakty z osobami spoza } \\
\text { wspólnoty. }\end{array}$ \\
\hline Spirytualny & $\begin{array}{l}\text { Wspólnota rodzinna ma za zadanie tworzyć warunki dla rozwoju } \\
\text { duchowości dorastajqcych. }\end{array}$ \\
\hline
\end{tabular}

Źródło: Opracowanie własne na podstawie: J. Mastalski, Zaniedbane paradygmaty formacyine nastolatka, „Studia Paedagogica Ignatiana” 2017, t. 20, nr 2, s. 103-1 18.

Wykorzystując koncepcję zaniedbanych paradygmatów formacji nastolatków, opracowaną przez ks. Janusza Mastalskiego, wybitnego

13 Por. J. Mastalski, Zaniedbane paradygmaty formacyjne nastolatka, „Studia Paedagogica Ignatiana” 2017, t. 20, nr 2, s. 103-118. 
znawcę pedagogiki rodziny, można podjąć próbę opisania treści i zakresów oraz znaczenia i roli funkcji pedagogicznych, jakie stawia się obecnie rodzinom żyjącym w czasach chaosu aksjonormatywnego.

\section{Funkcje pedagogiczne rodziny w czasach chaosu aksjonormatywnego}

Bez względu na to, czy mamy do czynienia z tradycyjną, czy zmodernizowaną przez współczesne przemiany wspólnotą rodzinną, czy też z rodzinami alternatywnymi, dostrzec należy w nich zawsze środowisko, w którym potomstwo bezwarunkowo zajmuje znaczące miejsce. Tym samym każdy z wymienionych typów rodzin staje przed realizacją jednej z najważniejszych funkcji, a mianowicie funkcji pedagogicznych. Zostały one opisane w literaturze dosyć szczegółowo, zwłaszcza w literaturze socjologicznej, ale $\mathrm{z}$ reguły odnoszono je do modelu rodzin tradycyjnych. W czasach chaosu aksjonormatywnego, którym towarzyszy wzrost liczby wspólnot wielorodzinnych i rodzin alternatywnych, wymagają one niejako nowego oglądu. Do obligatoryjnych funkcji pedagogicznych wszystkich wymienionych wcześniej typów rodzin, ale także wspólnot rodzin tradycyjnych, należy zaliczyć: funkcję pielęgnacyjno-opiekuńczą, socjalizacyjno-wychowawczą oraz edukacyjno-kulturową.

Funkcja pielęgnacyjno-opiekuńcza obejmuje zobowiązania wszystkich rodziców do zaspokajania podstawowych potrzeb każdego dziecka. Są to potrzeby, które można określić mianem potrzeb egzystencjalnych, utrzymujących potomstwo przy życiu biologicznym oraz wspomagających i wspierających naturalny rozwój potomstwa. Dotyczą one pielęgnacji dziecięcego organizmu, zachowania bliskości rodzinnej poprzez okazywanie czułości i miłości, które gwarantują potomstwu poczucie bezpieczeństwa. Rodzi się pytanie: czy współczesne dorosłe społeczeństwo, uczestniczące na różne sposoby w życiu przepełnionym trudnościami materialnymi, wewnętrznymi konfliktami natury moralnej, przeżywające frustracje $\mathrm{z}$ racji licznych niepowodzeń indywidualnych/osobistych, dotknięte stresem, nie radzące sobie z wypełnianiem ról społecznych, nierzadko „wypalone” zawodowo, a także nie przygotowane do odpowiedzialnego rodzicielstwa, jak np. młodociane matki, wywiązuje się ze swoich obowiązków 
i powinności względem własnego i powierzonego mu potomstwa zgodnie z oczekiwaniami społecznymi? Jakże często dzieci już po urodzeniu zostają porzucane, zaniedbywane, maltretowane fizycznie, a nawet molestowane seksualnie. Jakże często rodzice budujący nowe wspólnoty rodzinne zapominają o obowiązku kontynuowania opieki, czy alimentowania dzieci z poprzedniego związku małżeńskiego/partnerskiego. Takie postawy są skutkiem wszechobecnego współcześnie chaosu aksjonormatywnego, w którym coraz mniej jest miejsca i czasu na codzienną kontrolę własnych zachowań i postępowania. Chaos ten zakłóca wewnętrzny mechanizm ich oceny, jakim jest sumienie będące „specyficznie ludzką zdolnością oceny własnych działań przez odwoływanie się do etycznych pojęć dobra i zła oraz aprobowanej hierarchii wartości” ${ }^{14}$. Chaos aksjonormatywny powoduje degenerację sumienia współczesnego człowieka, które staje się niewrażliwe, „uśpione” a nawet ubezwłasnowolnione przez zawładające nim, często nawet wbrew jego woli, bodźce dehumanizacyjne.

Funkcja socjalizacyjno-wychowawcza sprowadza się do wprowadzania potomstwa w realną, a nie wirtualną rzeczywistość społeczną, która opiera się na normach zwyczajowych, obyczajowych i tradycji akceptowanych przez najbliższe środowisko, czy szeroko rozumiane społeczeństwo. Każda wspólnota rodzinna, bez względu na jej typ, jest zobowiązana do kierowania naturalnymi dążeniami ekspansywnymi swojego potomstwa, co czyni poprzez wyraziste uświadomienie sobie celów i zadań wychowawczych oraz doboru metod i środków ich realizacji. Dążenia ekspansywne zakorzenione są w każdym człowieku zarówno genetycznie, jak w wyniku mechanizmów poznawczych, które w wieku dorastania znacznie się zwiększają. Dotyczą one zarówno dojrzewania intelektualnego, emocjonalnego, biologicznego, czy społecznego. Stąd u dzieci i młodzieży dążenia do osiągania różnych sprawności, domaganie się respektowania przynależnych im praw, a także praw przynależnych osobom dorosłym. Pojawia się chęć dominacji, poczucie niezależności, wzmożona agresja wobec rówieśników, bunt okazywany rodzicom i osobom dorosłym. Są to przejawy zachowań potwierdzające zwiększającą się aktywność w uczestniczeniu w czymś ważnym w życiu i próbą

14 A.E. Gała, Uwarunkowania wychowawcze dojrzatej moralności, Lublin 1992, s. 25 . 
przeciwdziałania nudzie, bierności czy apatii. Są one także fundamentem odkrywania siebie samego i sensu swojego życia. Odkrywanie siebie i sensu własnego życia jest zakłócane niskim poziomem świadomości wychowawczej rodziców, zaś przede wszystkim brakiem subtelnej, a nawet intuicyjnej kontroli z ich strony nad codzienną organizacją życia dzieci i młodzieży. Lukę tę wypełniają treści, jakie niosą ze sobą media i urządzenia wytwarzane przez najnowsze technologie cyfrowe. Chociaż są one niezbędne w procesie gromadzenia informacji o świecie, to nierzadko powodują, że dorastający zaczynają żyć w świecie wirtualnym, a więc nie zawsze realnym, czyli prawdziwym obrazie świata. Nie zawsze są one sprzymierzeńcem procesów wychowawczych, a co gorsze mogą w znacznej mierze przyczyniać się do deformacji psychiki młodego człowieka. Treści przez nie przekazywane nie są poddawane weryfikacji przez rodziców o niskiej kulturze pedagogicznej. Funkcja socjalizacyjno-wychowawcza nakłada na rodziców powinność obnażania obrazu nieprawdziwego świata, ukazywania niebezpieczeństw, jakie on niesie, przyczyniając się do próby zdominowania intelektualnego, moralnego, duchowego i estetycznego wymiaru każdego dorastającego.

Funkcja edukacyjno-kulturowa obejmuje swym zasięgiem rodzicielskie postawy i działania zmierzające do wyposażenia potomstwa w wiedzę i umiejętności niezbędnych do życia we wspólnocie rodzinnej i wspólnotach lokalnych, ponadlokalnych środowiskowych, narodowych i międzynarodowych, czy wreszcie w różnych strukturach zrzeszających ludzi. Podstawą tej funkcji jest komunikacja interpersonalna zachodząca pomiędzy dorosłymi a dorastającymi, autentyczny, codzienny dialog międzypokoleniowy, wyznaczony potrzebami poznawczymi wszystkich podmiotów współczesnych wspólnot rodzinnych. Powinnością rodziców jest rozeznanie tych potrzeb u potomstwa, które zaspokajają głód jego wiedzy o świecie otaczającym, możliwość jej rozumienia i subiektywnego przyswajania. Funkcja ta spełnia rolę delikatnego wyczuwania i przekazywania wartości moralnych, religijnych i estetycznych, które zbliżają każdego człowieka do pragnienia uzyskania wewnętrznej harmonii oraz odkrywania etycznych ideałów, potrzeby uczestniczenia w przeżyciach transcendentnych i wrażliwości na piękno, które mają na celu uszlachetnienie każdej jednostki. Czy w pogmatwanym chaosie współczesnego świata globalnego i lokalnego tradycyjna wspólnota 
rodzinna, a zwłaszcza wspólnota wielorodzinna, bądź alternatywna jest w stanie w sposób optymalny spełniać tę funkcję? Czy poziom świadomości wychowawczej i kultury pedagogicznej tych rodzin jest obecnie zadowalający, aby czuwać nad wzrostem etycznym, religijnym, estetycznym swojego potomstwa? Nie chodzi o sprawne manipulowanie technikami wychowawczymi, które wykazują się liberalnym czy autokratycznym stylem oddziaływań na dzieci i młodzież, chroniąc i uodparniając je tym samym przed negatywnymi skutkami wszechobecnego chaosu aksjonormatywnego, który wywiera swoje piętno na rozwoju potomstwa i codziennego życia każdej rodziny. Chodzi o jakościową dojrzałość rodziców, którzy sami doświadczają negatywnych skutków zmian zachodzących we wszystkich przestrzeniach codziennego życia ludzkiego.

Rozumienie znaczenia funkcji pedagogicznych rodziny, respektowanie ich roli oraz kierowanie się nimi we wszystkich wspólnotach rodzinnych jest drogą optymalizującą wspomaganie potomstwa w dochodzeniu do dojrzałej dorosłości. Wspomaganie jest procesem długotrwałym, dynamicznym i ciągłym w przeciwieństwie do wsparcia, które należy pojmować jako jednorazowy akt sytuacyjny. Funkcjom pedagogicznym przypisać należy pewną intencjonalność umożliwiającą rodzicom ukierunkowanie potomstwa na samodzielność w podejmowaniu problemów życiowych i rozwiązywaniu zadań z nich wynikających. Prawidłowe wypełnianie funkcji pedagogicznych w każdej rodzinie minimalizuje zagrożenia, jakie niesie ze sobą współczesny chaos aksjonormatywny i przyczynia się do kształtowania samoświadomości dorastających, czyli pobudza ich do refleksji o sobie samych, do zdolności poznawania siebie jako podmiotu tworzącego własny obraz świata, w którym żyje. Właściwie wypełniane funkcje pedagogiczne rodziny przyczyniają się do odkrywania przez potomstwo sensu własnego życia.

\section{Zakończenie}

Rodzina jest przedmiotem uwagi wszystkich cywilizowanych społeczeństw, dla których zawsze stanowiła i nadal stanowi niepodważalną wartość. Jej fenomen stanowi przedmiot dociekań tak filozofów, jak i teologów oraz przedmiot poznania nauk szczegółowych. Każda $\mathrm{z}$ nich bada rodzinę $\mathrm{w}$ innym aspekcie, co świadczy 
o doniosłości, znaczeniu i roli rodziny w życiu każdego człowieka. Minione epoki historyczne potwierdzają zmienność cech rodziny. I chociaż współczesne nauki, zwłaszcza humanistyczne i społeczne, wiele o nich już wiedzą, dostrzegając dynamikę owej zmienności, to stale odkrywają nowe problemy i formułują pytania dotyczące wymiaru ich ontologicznego i epistemologicznego. Dynamiczne zmiany, jakie dokonują się w życiu rodziny wymagają nie tylko dalszych jej badań, ale także nowych podejść metodologicznych i strategii poznawczych. $Z$ pewnością nie jest dzisiaj aktualne twierdzenie mówiące, że rodzina jest „nadbadana”, że już o niej wszystko wiemy i nauka nie jest w stanie niczego nowego wnieść do opisu i wyjaśnienia zawiłości życia rodzinnego.

Upowszechniające się zjawisko nowych, często różniących się od siebie form życia rodzinnego, odmiennych od tkwiącego w świadomości obrazu tradycyjnych wspólnot rodzinnych, skłania do pełniejszego ich rozeznania poprzez poznanie rozumiejące właściwości, następstw i skutków, jakie one ze sobą niosą. Każda nowa forma życia wspólnoty rodzinnej jest zakorzeniona nie tylko w historii rodziny pochodzenia jej członków, zwłaszcza rodziców, lecz także niesie ze sobą filogenetyczne zasoby ukształtowane i uznane przez kolejne pokolenia.

Dla każdej wspólnoty rodzinnej conditio sine qua non są wielorakie więzi i relacje zachodzące pomiędzy członkami tej wspólnoty od początków jej zaistnienia. Więzi te obejmują wymiar biologiczny, emocjonalny, kulturowy i ekonomiczny. To one są fundamentem życia rodziny i relacji osobowych jej członków. Ich osłabienie, częściowe lub całkowite zerwanie sprzyja demoralizacji, relatywizmowi moralnemu, nihilizmowi etycznemu i deprawacji, przez co rodziny stają się dysfunkcjonalne, a i nieraz patologiczne.

Bez względu na formy życia wspólnot rodzinnych na szczególną uwagę zasługuje ich potomstwo. Wobec niego każda rodzina ma obowiązek i powinność wypełniania także podstawowych funkcji pedagogicznych. Ich znaczenie jest nie do przecenienia, gdyż mają one gwarantować jak najbardziej optymalny przebieg procesu dorastania dzieci i młodzieży do osiągnięcia wielostronnej dojrzałości zmniejszać następstwa negatywnych skutków współczesnego chaosu aksjonormatywnego. 


\section{Bibliografia}

Bauman Z., Ptynna nowoczesnośc, Wydawnictwo Literackie, Kraków 2006.

Bieleń R., Duszpasterstwo rodzin we wspótczesnej Polsce, Redakcja Wydawnictw KUL, Lublin 2001.

Fromm E., O sztuce mitości, przeł. A. Bogdański, Wydawnictwo Naukowe PWN, Poznań 2000.

Gała A.E., Uwarunkowania wychowawcze dojrzatej moralności, Katedra Psychologii Wychowawczej KUL, Lublin 1992.

Gawęcka M., Poczucie osamotnienia dziecka w rodzinie wtasnej, Wydawnictwo MADO, Torun 2004.

Jan Paweł II, Adhortacja apostolska Familiaris consortio, Rzym, 22 listopada 1981.

Jan Paweł II, List do rodzin Gratissimam sane, Rzym, 2 lutego 1994.

Kaja B.M., Psychologia wspomagania w rozwoju. Zrozumié świat życia cztowieka, GWP, Sopot 2010.

Kawula S., Brągiel J., Janke A., Pedagogika rodziny, Wydawnictwo Adam Marszałek, Toruń 1997.

Kępiński A., Poznaj siebie, Wydawnictwo Literackie, Kraków 2004.

Klimowicz G., Przeciwko bezradnej samotności, Nasza Księgarnia, Warszawa 1988.

Mastalski J., Jak dobrze wychować dziecko, Salwator, Kraków 2014.

Mastalski J., Zaniedbane paradygmaty formacyjne nastolatka, „Studia Paedagogica Ignatiana” 2017, t. 20, nr 2, s. 103-118.

Olearczyk T.E., Sieroctwo i osamotnienie. Pedagogiczne problemy wspótczesnej rodziny, Wydawnictwo WAM, Kraków 2007.

Pedagogika wobec zagrożen, kryzysów i nadziei, red. T. Borowska, Oficyna Wydawnicza „Impuls”, Kraków 2002.

Sztompka P., Świat potrzebuje wizji, „Alma Mater. Miesięcznik UJ” 2002, nr 44.

Tchorzewski A.M. de, Rodzina w kontekście wspótczesnych problemów egzystencjalnych $i$ pedagogicznych, w: Z dziejów polskiej kultury $i$ oświaty od średniowiecza do początków XX wieku, red. K. Jakubiak i in., Oficyna Wydawnicza Impuls, Kraków 2010.

Toffler A., Szok przysztości, przeł. W. Osiatyński, Zysk i S-ka, Poznań 1998. Wspótczesna rodzina polska - jej stan i perspektywy, red. H. Cudak, H. Marzec, t. 1-2, Górnośląska Wyższa Szkoła Pedagogiczna, Mysłowice 2005.

Wychowanie w rodzinie od starożytnosici po wiek XX, red. J. Jundzilł, WSP, Bydgoszcz 1994. 


\section{ADRES DO KORESPONDENCJI}

Prof. dr hab. Andrzej Michał de Tchorzewski

Akademia Ignatianum w Krakowie

Wydział Pedagogiczny

Instytut Nauk o Wychowaniu

e-mail: andrzejdetchorzewski1 @wp.pl 